\title{
Linzizong Volcanic Rocks in Linzhou of Tibet: A Volcanic Petrologic Assemblage in Continental Collision Environment
}

\author{
Guochen Dong*, Xuanxue Mo, Zhidan Zhao, Liang Wang and Su Zhao \\ Earth Sciences and Land Resources School, China University of Geosciences (Beijing), 29 Xueyuan Road, Haidian District, 100083 \\ Beijing, CHINA \\ *Towhom correspondence should be addressed.E-mail: guochdong@263.ent
}

Cenozoic Linzizong volcanic rocks, originally named as Linzhou volcanic basin, southern Tibet, are widely spread in Gangdese magmatic belt and unconformably overlain by the late Mesozoic sedimentary sequences. These consist of a set of potassic moderate to acid volcanic rocks including the basaltic andesite, andesite, dacite, trachyandesite, shoshonite, rhyolite and their related pyroclastic rocks with interlayers of sedimentary rocks, which can be divided into 3 categories: Dianzhong Formation, Nianbo Formation and Pana Formation. Based on petrology and geochemistry, $\mathrm{K}_{2} \mathrm{O}$ and $\mathrm{Al}_{2} \mathrm{O}_{3}$ contents in volcanic rocks increase from bottom to top, changing from potassic to highly potassic field in $\mathrm{K}_{2} \mathrm{O}-\mathrm{Na}_{2} \mathrm{O}$ diagram, and from sub-aluminous to peraluminous. It tends to evolve to acid from moderate and develops huge thick pyroclastic flows in the upper part, responding significantly to the thickening of the crust in the later stage. The volcanic rocks are enriched relatively in $\mathrm{Cs}, \mathrm{Rb}, \mathrm{K}, \mathrm{U}$ and deplete $\mathrm{Ta}, \mathrm{Nb}, \mathrm{Ti}, \mathrm{Sr}, \mathrm{Ba}$ and $\mathrm{P}$. Spider diagrams and REE pattern of the Linzizong volcanic rocks show similar characteristics with post-collisional highly potassic volcanic rocks in the Gangdese magmatic belt. ${ }^{40} \mathrm{Ar} /{ }^{39} \mathrm{Ar}$ isotopic isotopic dating has constrained the age of formation at 43.93-64.43 Ma for the Linzizong volcanic rocks, in which Dianzhong Fm formed during 61.45-64.43 Ma, Nianbo Fm. 54.07-50 Ma and Pana Fm 43.93- 48.72Ma. The strata across the unconformity were tremendously different in sedimentary facies and structural deformation, implying a major tectonic event. The formation of the unconformity was constrained by ${ }^{40} \mathrm{Ar} /{ }^{39} \mathrm{Ar}$ age ( $\left.~ 65 \mathrm{Ma}\right)$ of the basal andesite of Linzizong volcanic strata. In combination with evidence from the temporal evolution and spatial distribution of igneous rocks in Tibetan Plateau, and the stratigraphical and paleontological evidences in southern Tibet that documented dramatic change in sedimentary facies and microfuna content across the Cretaceous-Tertiary (K/T) boundary, it is concluded that the collision between India and Eurasia continents was most likely initiated at $\sim \mathrm{K} / \mathrm{T}$ boundary time and that Linzizong volcanic rocks, as volcanic assemblage produced during continental collision to post-collision, were recoding the transitional process from beginning of the collision to post-collision between Indian and Eurasian continents during Paleocene to Eocene (65-40 Ma). While the volcanic rocks formed in early stage, it had fingerprints of continental margin-arc settings, those in middle and late stages reflected environments of intra-continental convergence and crust thickening.

\section{Refenences}

Xuanxue Mo, Jinfu Deng, and Chonghe Zhao. 2003. Response of the volcanism to the India-Asia collision. Earth Science Frontiers10 (3): $135-148$

Mo X, Z Zhao, and S Zhao. 2002. Evidence for timing of the initiation of India -Asia collision from igneous rocks in Tibet [J]. EOS Trans, 83 (47)

Mo X, J Deng, and ZZhao. 2003. Volcanic records of India-Asia collision and post-collision processes. Proc. EGS-AGU-EUGJoint Assembly (Nice)[C]., 263.

Dong Guochen, Xuanxue Mo, and Zhidan Zhao.In press. A New Study on the Stratigraphy Sequences of Linzizong Volcanic Rocks in Linzhou Basin, Tibet. Geol Bull China

Miller, C, R Schuster, and U Kloetzli. 1999. Post-collisional potassic and ultrapotassic magmatism in SW Tibet; geochemical and Sr-Nd-Pb-O isotopic constraints for mantle source characteristics and petrogenesis. J Petrol 40(9): 1399-1424 